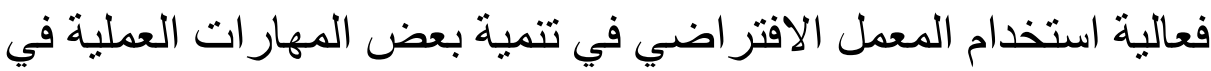

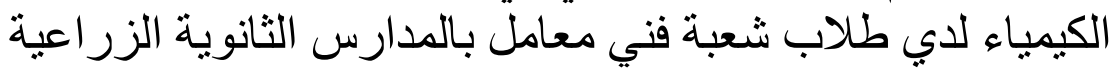

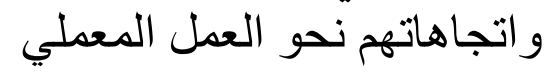

\title{
عايدة إبراهيم داود إبراهيم
}

إلى الثخص المسئول عن أعمال المعل الفنية

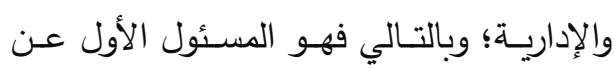

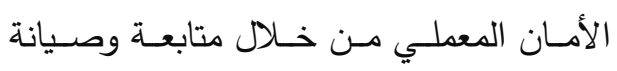
المعدل بمرافقه وتجهيزاته؛ من خـلال تجهيز

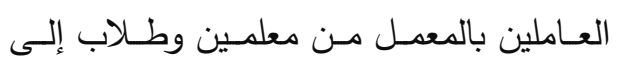

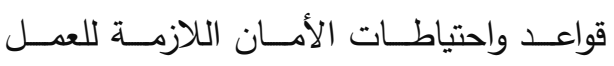

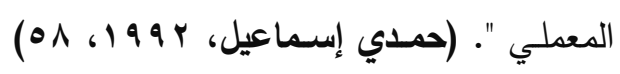

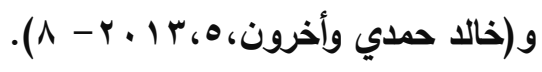

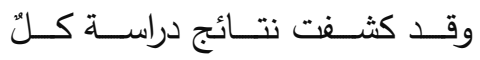
من (صبري باسط، ب9 9 1)، (ماجدة سليمان،

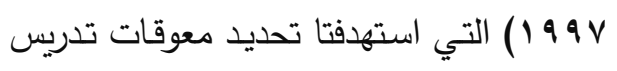

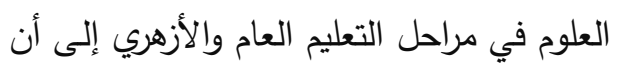
هناك معوقات متعلقة بمعامل العلوم منها: 1. بهوط المستوي الفني لأمين المعمل.

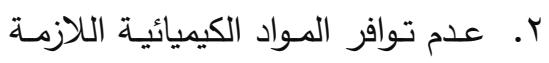

$$
\text { لإِجراء التجارب العملية. }
$$

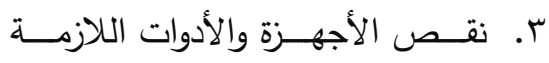

$$
\text { كالإجراء التجارب العملية. }
$$

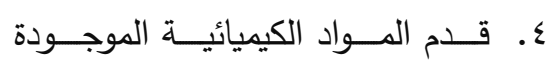

بالمعل وفقدانها لفعاليتها.

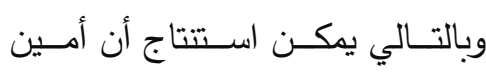

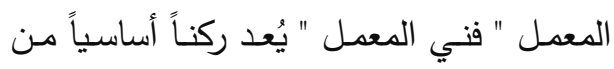

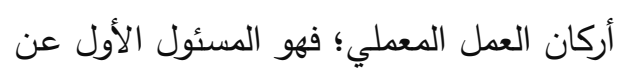

يثهد العالم تقدماً علمياً وتكنولوجياً؛

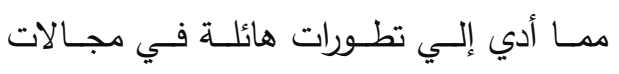

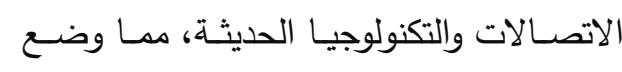
المتخصصين في مجـال التربيـة العلميـة أمسام تحـديات جسـيمة؛ تفــرض علــيهم المبـادرة

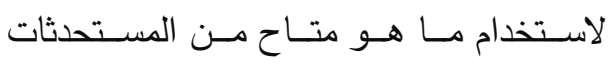

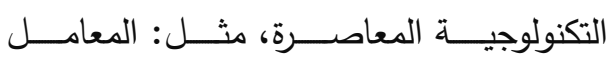
الإلكترونية ومنها المعامل الافتراضية.

وينفرد تدريس العلوم عن غيره من الإضية تريس المواد الآخري بارتباطه واهتمامه بإجراء

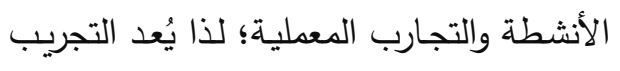

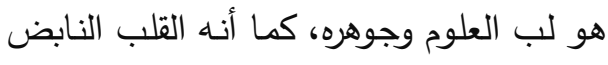
في تدريس العلوم في مراحل التعليم الدختلفة . مشكلة البحث : مئر في

يتقق خبراء التربية العلمية على أن

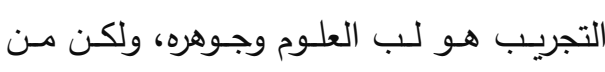

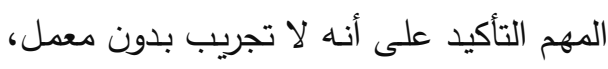

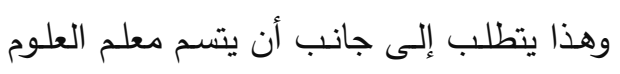

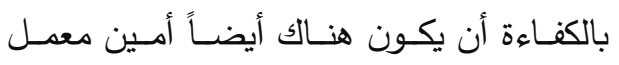

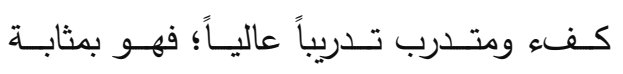
المساعد الأول لمعلم العلوم.

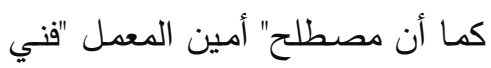
المعمل " مصطلح يشيع استخدامه في مصر المرين 


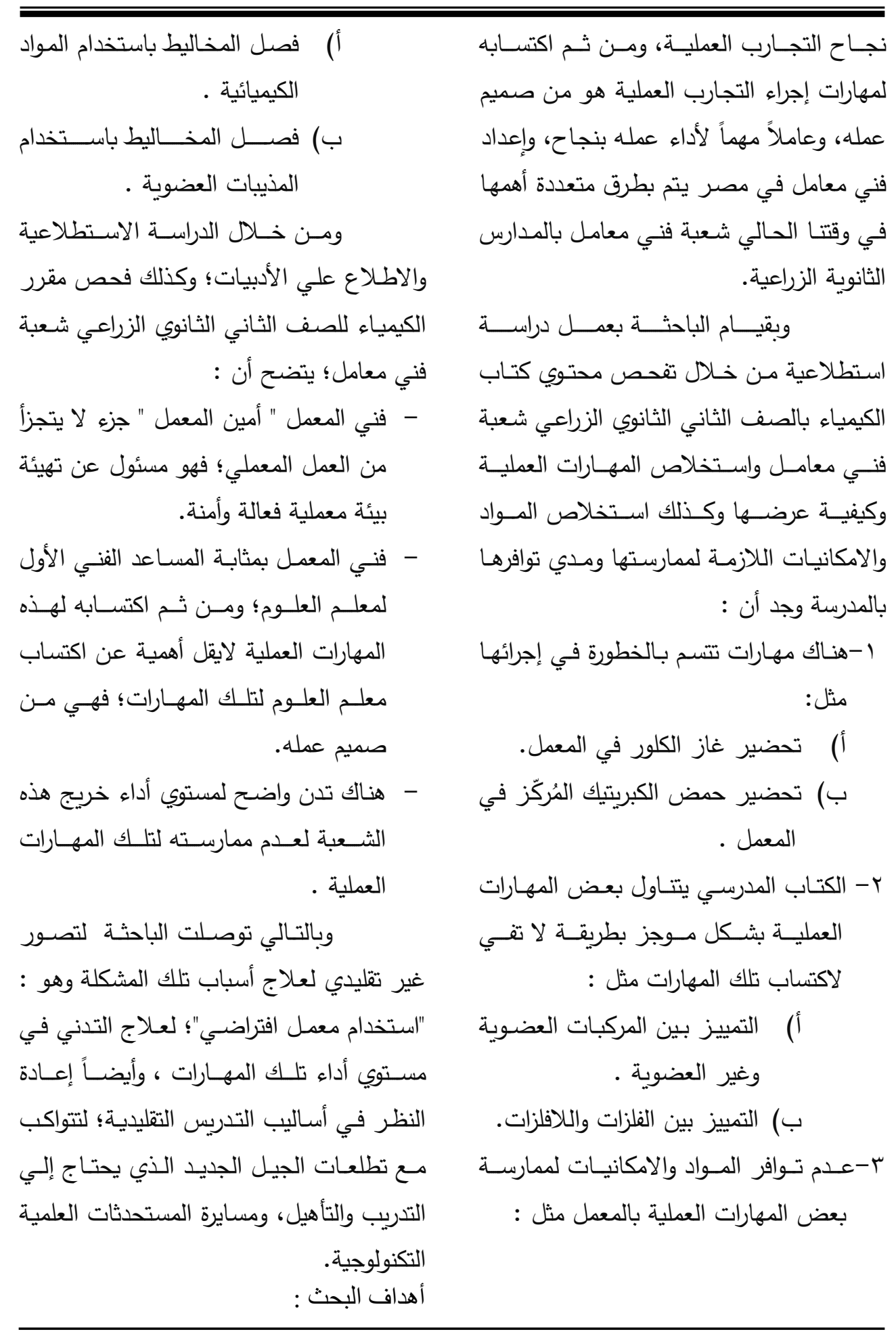




$$
\begin{aligned}
& \text { وضابطة بمدرستي كفر صقر وبني عبيد }
\end{aligned}
$$

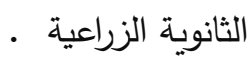

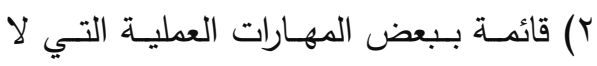

$$
\begin{aligned}
& \text { تتــوافر المــواد والإمكانيــات لممارســتها } \\
& \text { بالمدرسـة، ومهـارات آخري تُمثل خطورة }
\end{aligned}
$$

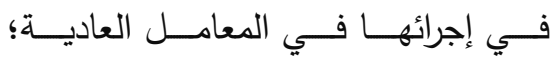

$$
\begin{aligned}
& \text { والمتضــــة بالوحـدة الأولـي فـي كتـاب المان } \\
& \text { الكيميـاء للصـف الثاني الثانوي الزراعي } \\
& \text { شـعبة فنـي معامـل فـي العـام الدراسـي لونسي }
\end{aligned}
$$

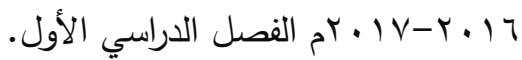

$$
\begin{aligned}
& \text { - التطبيق علي مجموعة البحث خلال الفصل التصل }
\end{aligned}
$$

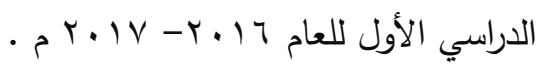

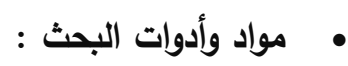

$$
\begin{aligned}
& \text { قامت الباحثة بإعداد ما يلي : } \\
& \text { أ) مواد البحث : تمثّلت مواد البحث في : }
\end{aligned}
$$

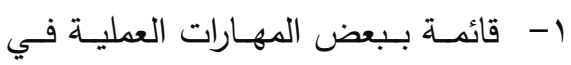

$$
\begin{aligned}
& \text { الكيمياء } \\
& \text { r- سيناريو مبدئي للمعدل الافتراضي في }
\end{aligned}
$$

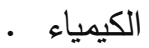

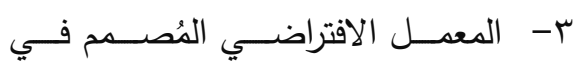

$$
\begin{aligned}
& \text { الكيمياء باستخدام البرامج :( الفـلاش، } \\
& \text { والفوتوشـوب، واسـكرين اسـكريبت ؟، } \\
& \text { • وسناجت) }
\end{aligned}
$$

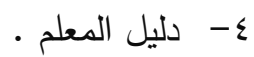

$$
\begin{aligned}
& \text { - - كراسة الأنشطة والتدربيات . } \\
& \text { ب) أدوات البحث: تمثّلت أدوات البحث في: } \\
& \text { استهدف البحث الحالي ما يلي : }
\end{aligned}
$$

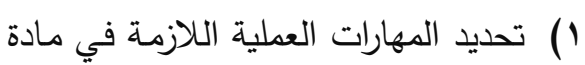

$$
\begin{aligned}
& \text { الكيمياء للدي طـلاب شعبة فني معامل }
\end{aligned}
$$

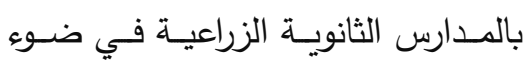

$$
\begin{aligned}
& \text { احتياجاتهم التدريبية . } \\
& \text { r إعـداد وتصـميم معمل افتراضـي مقتـرح }
\end{aligned}
$$

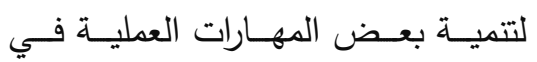

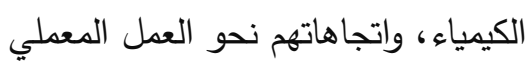

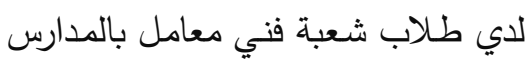

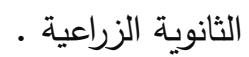

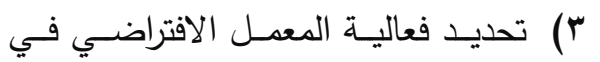

$$
\begin{aligned}
& \text { تتمية تحصيل الجانب المعرفي للمهارات } \\
& \text { العملية لدي طـلاب شعبة فنـي معامل } \\
& \text { بالمدارس الثانوية الزراعية. }
\end{aligned}
$$

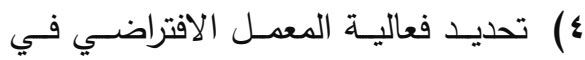

$$
\begin{aligned}
& \text { تتمية أداء بعض المهارات العملية لدي }
\end{aligned}
$$

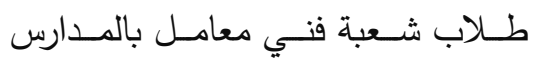

$$
\begin{aligned}
& \text { الثانوية الزراعية . }
\end{aligned}
$$

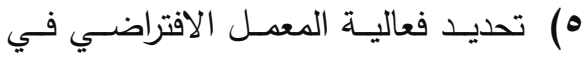

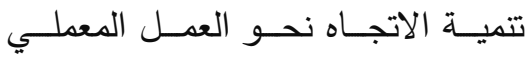

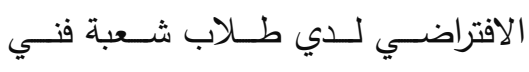

$$
\begin{aligned}
& \text { معامل بالمدارس الثانوية الزراعية . } \\
& \text { حدود البحث : } \\
& \text { اقتصر البحث الحالي علي : }
\end{aligned}
$$

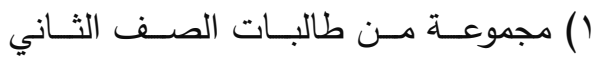

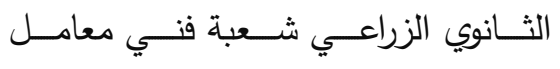

$$
\begin{aligned}
& \text { وتتقـــيمهم إلـــي مجمـــوعتين تجريبيـــة }
\end{aligned}
$$

\section{$r \wedge q$}




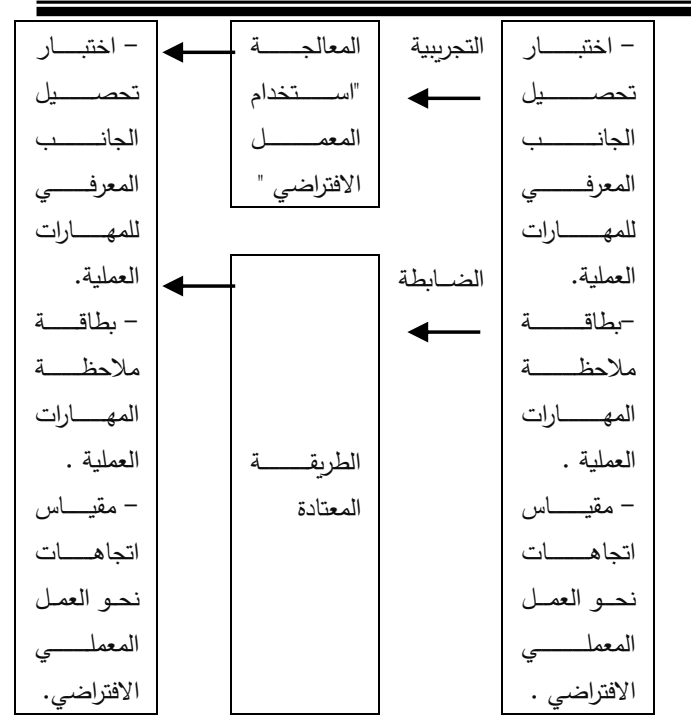

شكل رقم (1)

التصميم شبه التجريبي للبحث

تحديد مصطلحات البحث :

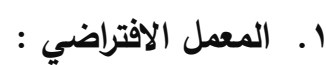

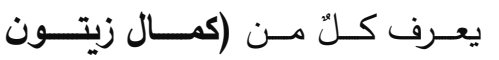

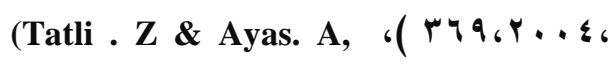
2012, 184)

منفتحسة يتم من خلالها محاكاة مختبر العلوم الحقيقي، والقيام بربط الجانب النظري بالجانب

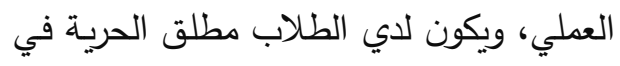

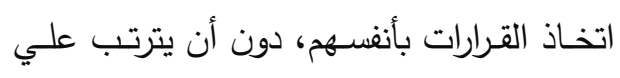
هذا القرار أية أثثار سلبية؛ فهو برنامج تفاعلي

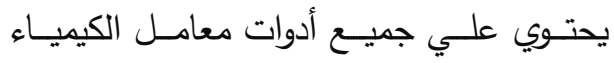
والفيزياء، واللازمة لإجراء التفاعلات الكيميائية والفيزيائية والتي تمكن المستخدم أيضاً من رسم جداول للنتائج وإعطاء تقارير حولها " . وتعرفه الباحثـة إجرائيـاً بأنسه:" بيئة تعلـيم وتعلـم افتراضـية، يـتم خلالهـا محاكـاة

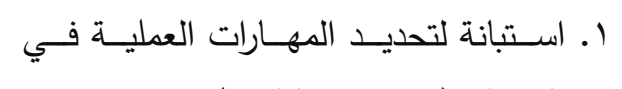

الكيمياء (من إعداد الباحثة) .

r. اختبار تحصيل الجانب المعرفي للمهارات

العملية (من إعداد الباحثة).

r. بطاقة ملاحظة بعض المهارات العملية في

الكيمياء (من إعداد الباحثة ) .

ع. مقيــاس الاتجــاه نحــو العمـلـ المعملـي

الافتراضي (من إعداد الباحثة) .

منهج البحث :

اسـتخدم فـي هـذا البحــث المـنهج

الفرضـي - الاسـتـلالي الـذي أصـطلح علـي

تسـميته المـنهج العلمسي فـي هـذا البحـث أو

المدخل الكمي وذلك في جوانبه :

أ) الوصــفية التحليليــة : الـذي تمثّـل فـي

استقراء البحوث والدراسات السابقة، وإعداد

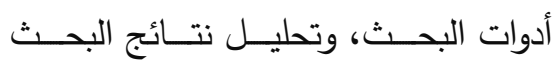

$$
\text { وتفسيرها ومناقشتها }
$$

ب) الشبه التجريبية : الذي تمثّل في التصميم

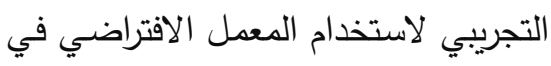

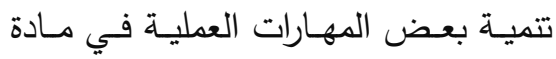
الكيمياء لدي الطلاب شعبة فني معامل لتصل واتجاهاتهم نحو العمل المعملي، وذلك عن طريـق تقسيمهم إلـي مجهوعتين تجريبيـة

وضابطة كما بالثكل (1) : التبليق 
ويعرف كلُ من (A.S.T.A,2010, 1

( U. S. B of (A.S.T.A,2013, 2) و (Stang.P,2014, و labor statistic , 2013, 3) (5) فني مختبر الكيميـاء بأنـهـ :" الثـخص المســول عـن تقــيم المســاعدة للكيميـائيين والمهندسين الكيميائيين في المختبر واستخدام

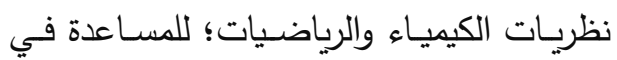
البحث وتطوير طرق لإنتاج مركبات كيميائية

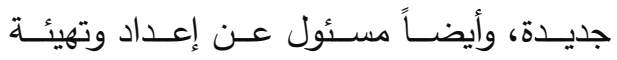

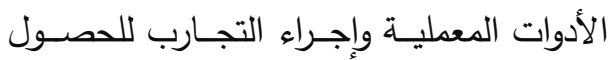
على نتائج جديدة وتجميع مواد كيميائية معينة وأداء التجارب والتحكم في العمليات الكيميائية وتحليل العينات وتتظيم نتائج التجارب ".

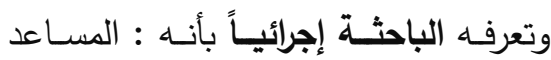

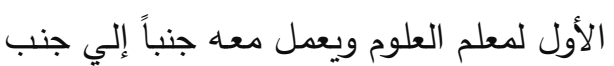
في المعمل، ويتسم بالسمات التالية:

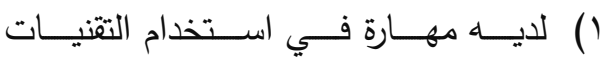

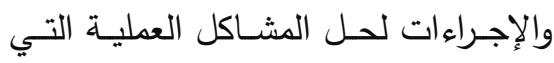
تتطلب البراعة والإبداع في العمل المعملي r) لايه القدرة علي تقديم الدعم والمساعدة في

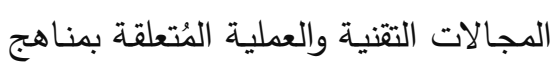

$$
\text { • العلوم }
$$

r) لديـهـ خبـرة علميـة في تحضـير الأدوات

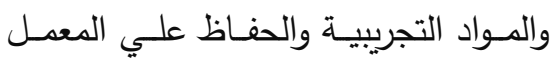

$$
\text { ومحتوياته . ولهواد }
$$

مختبـرات ومعامـل الكيميــاء؛ وذلــك بتطبيـق التجـارب العمليـة بثـكل افتراضـي؛ وبمـؤثرات

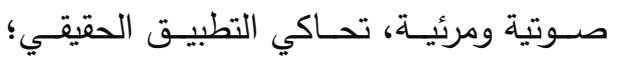
مستخدماً في ذلك أحدث البرمجيات للمعامل الافتراضية .

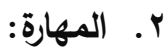

هي قدرة الطالب علي أداء مهمة ما بدقة وسرعة وإتقان وبأقل جهد ، سواء كانت هذه المهمة جهداً عقلياً أو عملاً يدوياً.

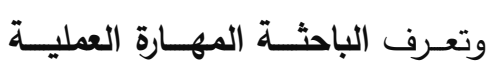
إجرائياً بأنها " قدرة الطالب شعبة فني معامل علي أداء المهام والتجارب العملية في الكيمياء باسـتخدام المعهـل الافتراضــي بدقـة وســرعة وإتقان وبأقل جهد. r. أمين المعدل "فنـي المعدل، التقني، فنـي

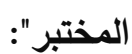

يعرف كلٌ من(Royal Society, 2001)

S.S.T.N.S, ‘CLEAPSS,2009 ，12)،(

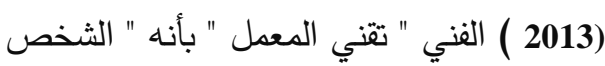

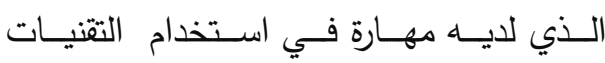

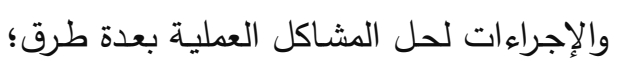
تتطلب البراعة والإبداع، وعادة الفنيون يتعاملون مـع الأدوات والمعدات المعقدة وتتطلب تدريباً متخصصـاً؛ بالإضـافة إلى الخبرة العلميـة في العي تحضير المواد التجريبيـة والحفـاظ على البنيـة التحتية للأنشطة". 
وتعرف الباحثة إجرائياً الاتجاه نحو

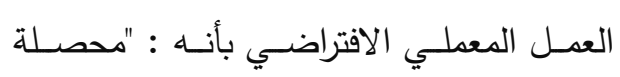
استجابة عينة البحث من طلاب الصف الثاني

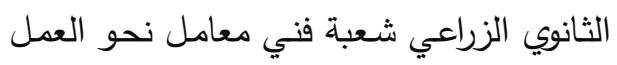

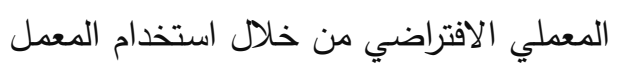

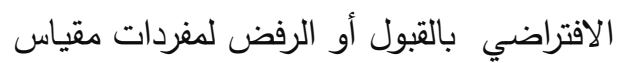
الاتجاه الذي أعدت الباحثة ".

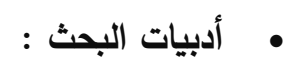

يتفق خبراء التربية العلمية علي أن التجريب هو لب العلوم وجوهره، وإن المختبر هو القلب النابض لتدريس العلوم في مراحل

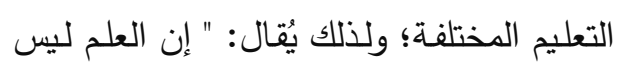

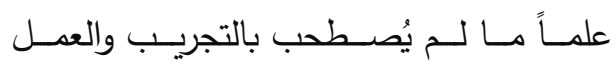

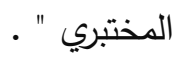

ويعتقد البعض أن العمل المعلي هو

نفس مفهوم التجريب المعملي، ولكن هذا خطأ؛

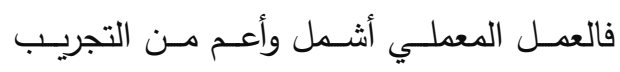
المعملي، كمـا أن التجريب المعملي جزءاً من فئن

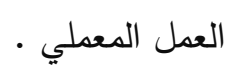

حيث أشـار ( محمــ السـيل علـي،

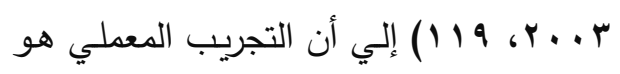

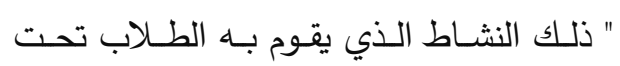
إثـراف المعلــ؛ بغيـة الحصـول علـي المعرفـة العلميـة، وحل المشكلات، واكتسـاب المهارات

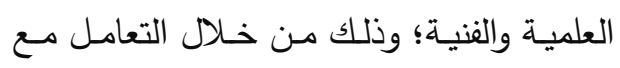
الأدوات والمـواد والأجهـزة، وممارســة عمليـات

$$
\text { العلم الأساسية والتكاملية " . الادواد والاجهة، ومار }
$$

؛) لديه القدرة علي استخدام نظريات الكيمياء

والفيزياء والرياضيات ذات العلاقة بالبحث

$$
\text { والتطوير في المختبر • }
$$

0) لديه القدرة علي إصـلاح وتزويد وتحضير فئير

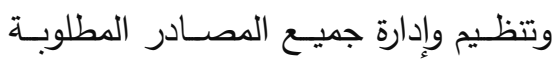
للأمن والسلامة لإجراء التجارب والأنشطة العملية .

7) ل لديـهـ مهــارات إعــاد المعـدات العلميـة وتحضير المحاليل المُستخدمة في معامل العلوم وتوجيه ومساعدة المعلمين والطلاب في اكتساب المهارات العملية . V يُدير المصادر الضرورية للأنشطة العملية لمعمل العلوم - لالاتحاه: ع. ع. الاتجاه:

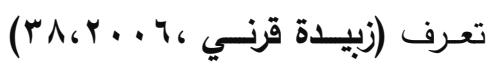

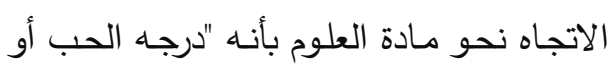
الكــره، أو الــرفض نــــــو العلــوم ودراســــها

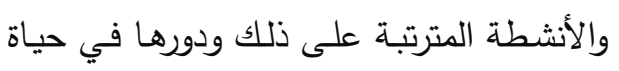
الفرد والمجتمع".

\section{ويعـرف (ممـــدوح عبـــــ المجيــــ}

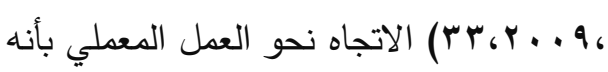

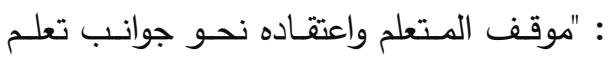

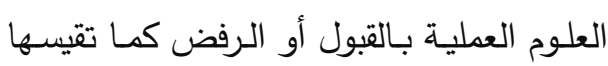

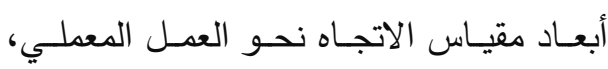
ويعبر عنها بالدرجة التي يحصل عليها المتعلم في المقياس ". 


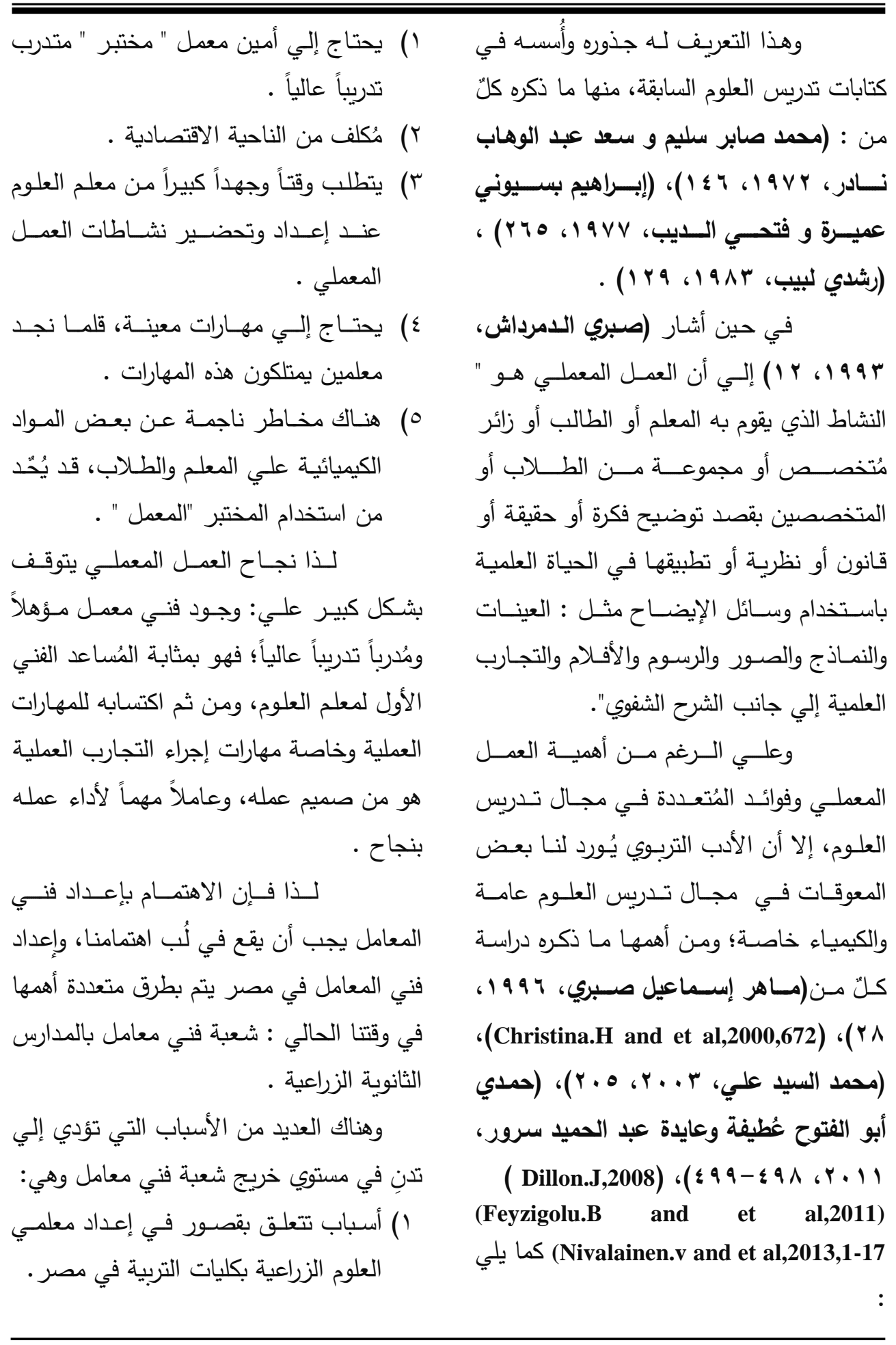


عاليـة؛ يـوفر بيئـة تعلـم اعتباريـة مُصـــنعة بـالكمبيوتر تُحسـاكي معامـل حقيقيـة، وتُمكّـن

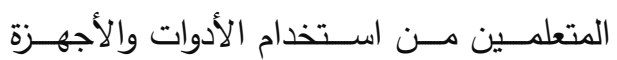

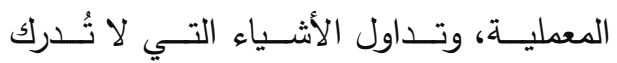

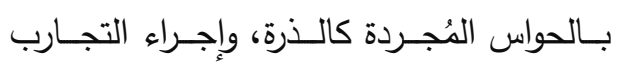
والفحوصات الصعبة والخطرة في بيئة أمنة . وهناك العديد من المميزات لاستخدام المعامل الافتراضية؛ حيث حددها كلٌ من : ، (Subramanian and Marsic, 2001)

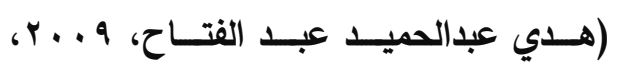
r ؛ \& ا ) و (المركز القومي للتعليم الإكترونسي

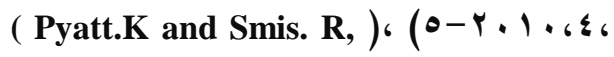
(Poulin.J et al,2013 ) ، 2012, 134 التالي : ( ) تعويض النقص في الإمكانيات المعملية الحقيقية؛ لعدم توفر التمويل الكافي . r) يتيح المعدـل الافتراضـي إمكانيـة إجـراء

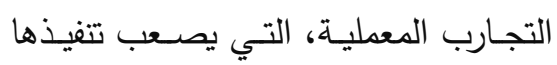
في المعامـل الحقيقيـة؛ بسـبب خطورتهـا علي المتعلم، مثل تجارب الطاقة النووية، أو الكيمياء، أو البيولوجيا الحيويـة وغيرهـا

ץ) إمكانية العرض المرئي للبيانات والظواهر التي لايمكن عرضها من خـلال التجارب التهاب الحقيقية كالشكل الغراغي للذرة. r) مشـكلات تتعلـق بـالمحتوي نفسـه" المـواد

التي يدرسها فني المعمل قبل الخدمة ".

ونختص هنـا بـالتركيز علـي المشككلات

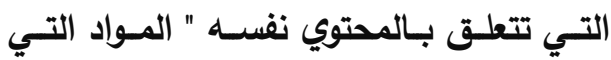
يدرسها فني المعمل قبل الخدمة " :

وفي هذا الصدد تقتصر الباحثة علي

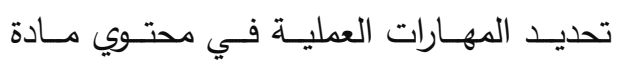
الكيمياء بالصف الثاني الثانوي الزراعي شعبة

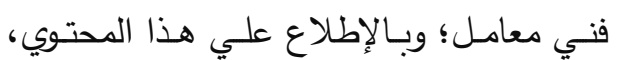
وُجد أن هنـاك مجموعـة من العقبات " أوجـه

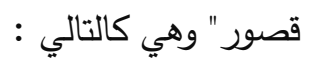
ا ـ الكتاب المدرسي يتـاول بعض المهارات

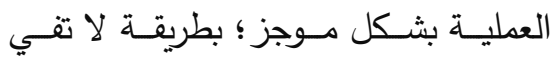

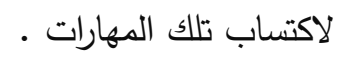
r. هناك مهارات تتسم بالخطورة في إجرائها . r. هناك مهارات لا تتوافر المواد والامكانيات

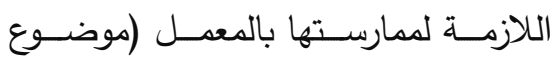
البحث) وتري الباحثة أنه يمكن استخدام المعامل

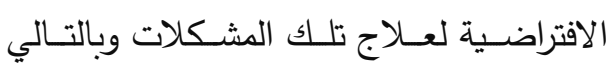
مسايرة المستحدثات العلمية التكنولوجية . ويُعـرف كـلُ مـن (محمــــ عطيـة

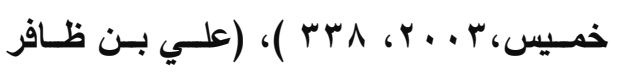

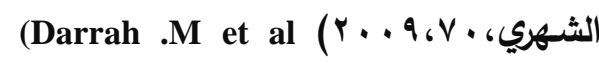
(Weisman.D, 2010, 23) 2014, 803) المعدل الافتراضـي بأنـه: "برنـامج كمبيـوتري تفــاعلي متعـدد الوسـائط ذا مواصـفات تثقنيـة لرنية 


\begin{tabular}{|c|c|}
\hline 0-يوجد فرق دال إحصائياً عند مستوى (0... & ع) دعم الاقتصاديات الضـيفة؛ بتوفير المواد \\
\hline ) بــين متوسـطي رتـب درجـات طــلاب & المُسـتهلكة، مثـل الكيماويـات، والوســائل \\
\hline المجموعـة التجريبيـة والمجموعـة الضــابطة & المعملية، ومكونات التجارب . \\
\hline في التطبيق البعدي لمقياس الاتجاه نحو & فروض البحث : \\
\hline العمــلـل المعملـــي الافتراضــــي لصـــالح & أمكن صياغة فروض البحث الحالي كالتالي: \\
\hline 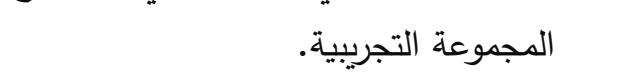 & 1-يوجد فرق دال إحصائياً عند مستوى (0., \\
\hline ؟-يوجــد فـرق دال إحصــائياً عنــد مسـتوى & • · ) بـين متوسـطي رتـب درجـات طـلاب \\
\hline (0...) بين متوسطي رتب درجات طلاب & المجموعـة التجريبيـة والمجموعـة الضـابطة \\
\hline المجموعة التجريبية في كل من القياسين & فـي التطبيـق البعـدي لاختبـار تحصـيل \\
\hline التبلي والبعدي لـقياس الاتجاه نحو العمل & الجانب المعرفي للمهارات العملية لصـالح \\
\hline المعملــي الافتراضـــي لصــالح التطبيـق & المجموعة التجريبية. \\
\hline البعدي. & ץ-يوجد فرق دال إحصائياً عند مستوى (0.,. \\
\hline خطوات البحث و إجر اءاته : & ) بـين متوســـي رتــب درجــات طــلاب \\
\hline لتتفيذ هذا البحث والإجابـة عن أسئلته قامت & المجموعة التجريبية في كل من القياسين \\
\hline الباحثة بالخطوات التالية : & القبلي والبعدي في اختبار تحصيل الجانب \\
\hline •الاطلاع علي البحوث والدراسـات السـابقة & المعرفي للمهارات العملية لصالح التطبيق \\
\hline والكتب والمراجع المتخصصة في المناهج & 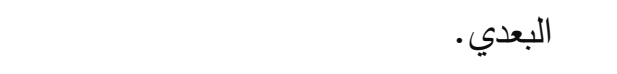 \\
\hline وطرق التدريس التي لها صلة بمتغيرات & ץ-يوجد فرق دال إحصائياً عند مستوى (0.,. \\
\hline الاراسة الحالية بهدف : & ) بــين متوسـطي رتــب درجـات طــلاب \\
\hline - - بيان موقف البحث الحالي وموقعه من هذه & المجموعة التجربيـة والمجموعـة الضـابطة \\
\hline البحوث والدراسات & فـي التطبيـق البعـدي لبطاقـة ملاحظـــة \\
\hline - - الإفادة منها في إجراءات البحث الحالي، & المهــارات العمليــة لصــالح المجموعــة \\
\hline وبنـاء أدواتـه، وتفسـير نتائجــه في ضـوء & التجريبية. \\
\hline مناقشة نتائج تلك البحوث والدراسات . & ـ - يوجـــ فـرق دال إحصــائياً عنـــد مســتوى \\
\hline - - وضـع إطار نظري للبحث الحالي للوقوف & (0...) بين متوسطي رتب درجات طلاب \\
\hline علي الأسس النظرية للمتغيرات. & المجموعة التجريبية في كل من القياسين \\
\hline • تحديــــ المهــارات العمليـة فـي الكيميـاء : & القبلي والبعدي لبطاقة ملاحظة المهارات \\
\hline والمتضمنة بمحتوي كتاب الكيمياء بالصف & العملية لصالح التطبيق البعدي. \\
\hline
\end{tabular}




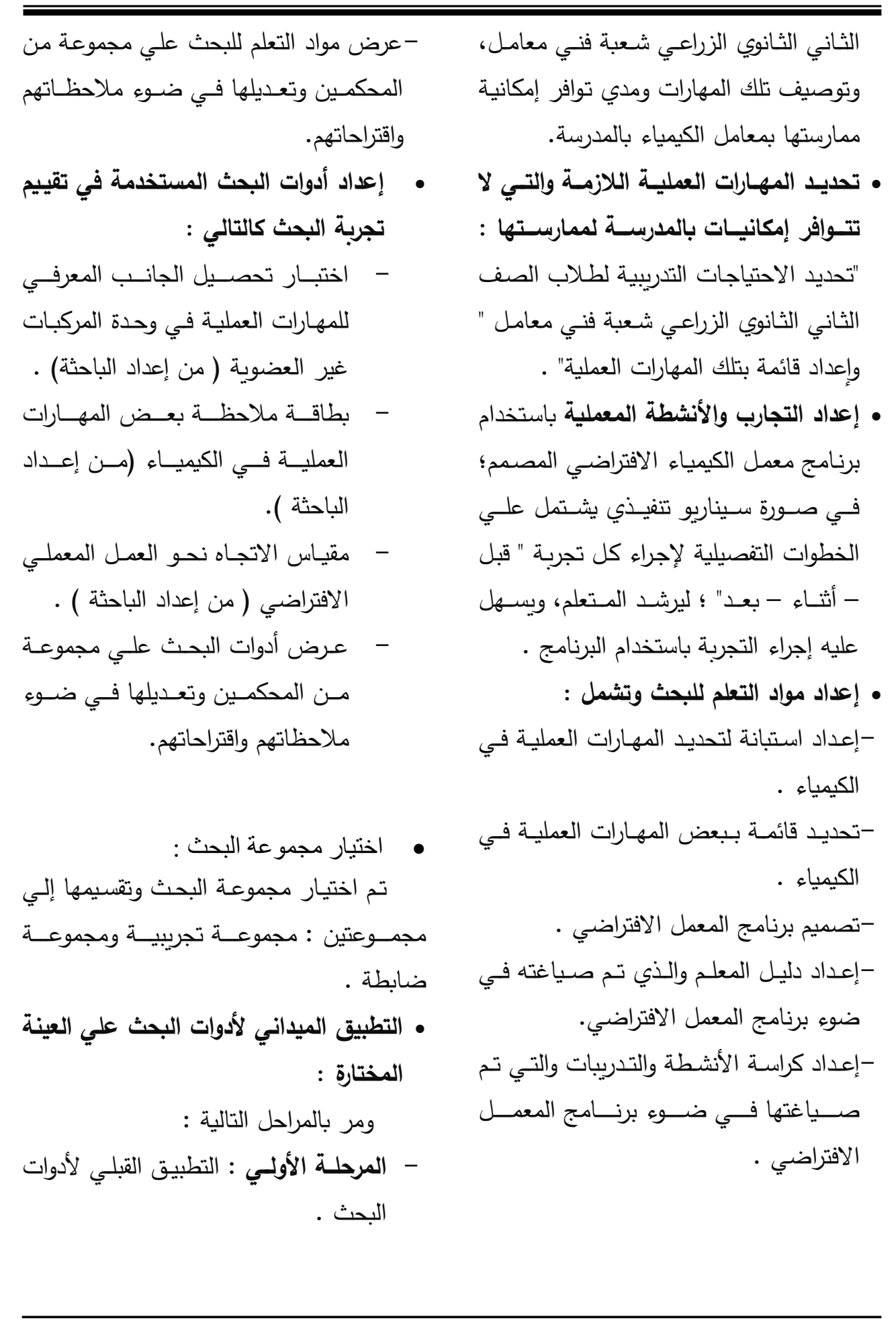




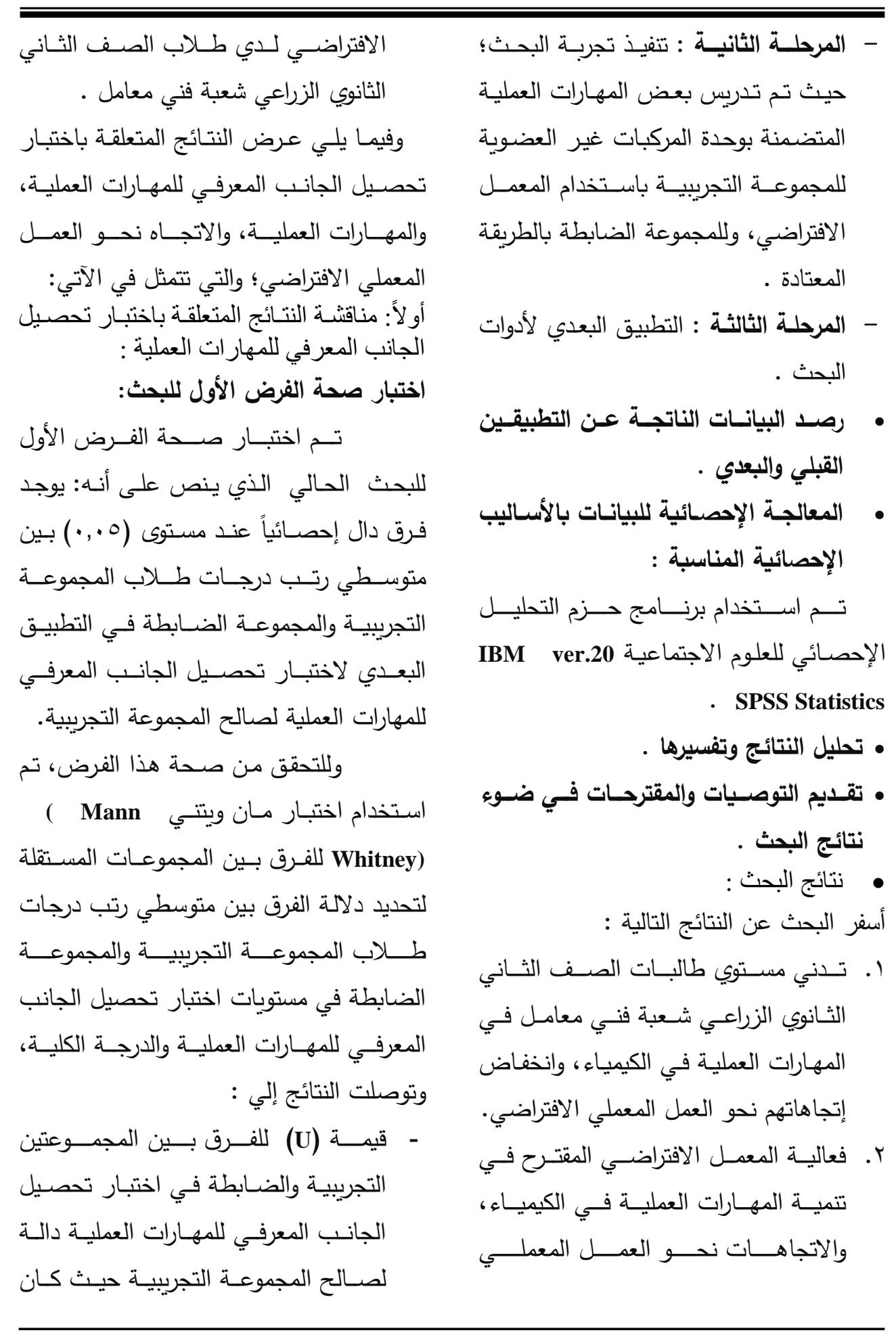




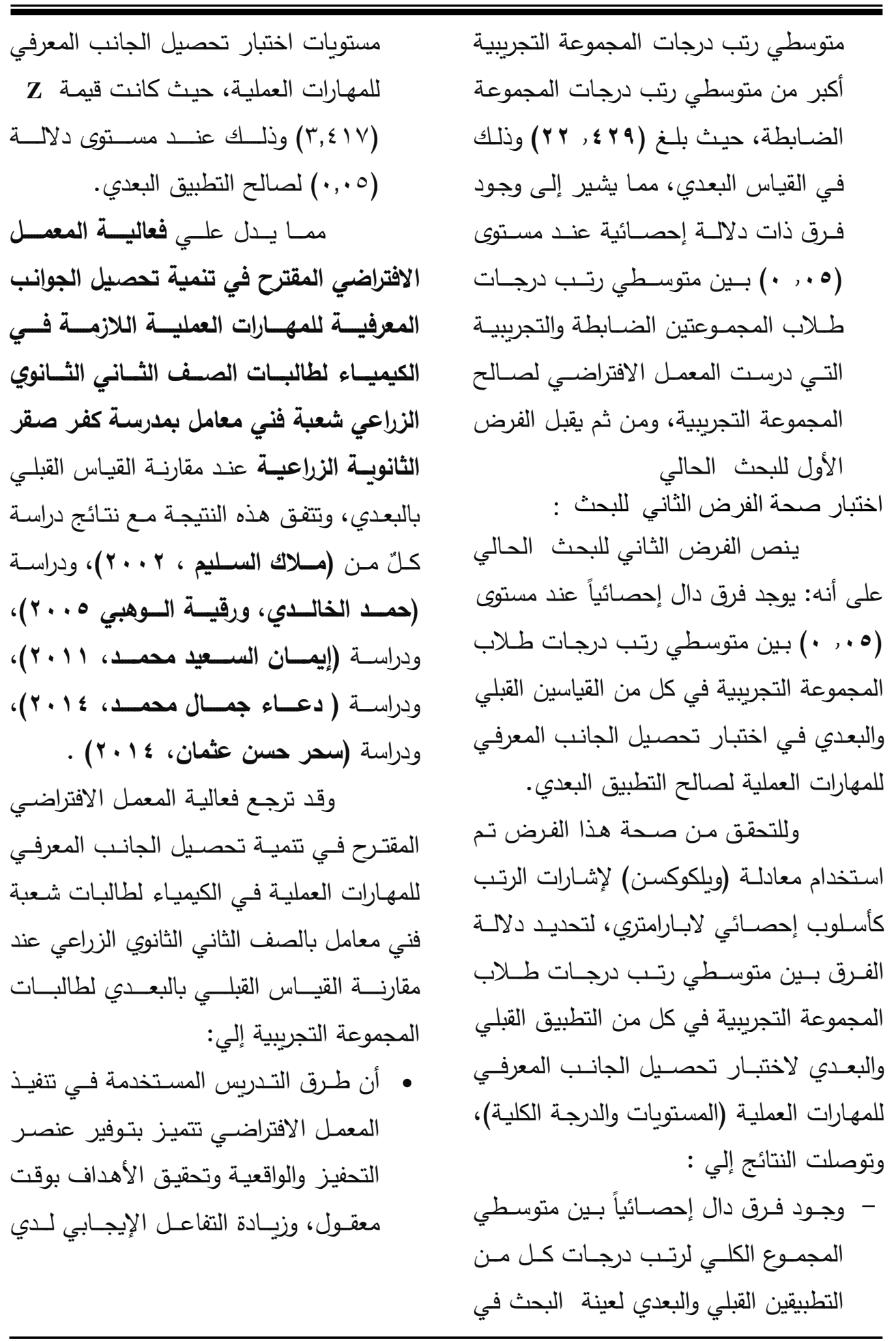




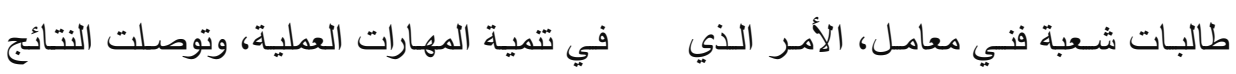
يؤثر بشكل إيجابي في زيادة تحصيلهم · إلي:

-وجـود فـرق دال إحصــائياً بـين متوسـطي

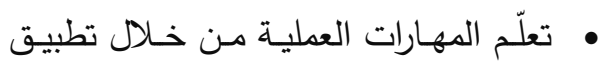

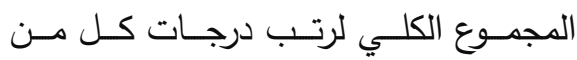

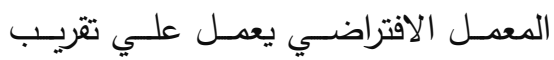
التطبيقين القبلي والبعدي لعينـة البحث في لرسب الهفاهيم المجردة؛ بحيث تُكسب الطالبات بطاقة ملاحظة المهارات العملية ككل، حيث ليثين

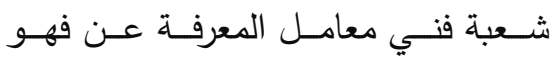
كانت متوسط الرتب ( . . . , ب (Y) وذلك عند مستوى (0... •) لصالح التطبيق البعدي. -قيمة (U) للفرق بين المجموعتين التجريبية والضـابطة فـي بطاقـة ملاحظــة المهـارات العمليـة دالــة لصـالح المجموعـة التجريبيـة حيث كان متوسطي رتب درجات المجموعة التجربيية أكبر من متوسطي رتب درجيات

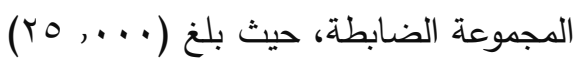
وذلك في القياس البعدي .

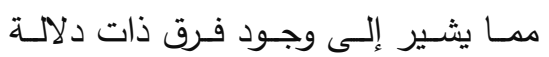

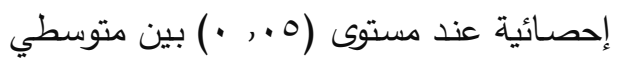
رتب درجـات طـلاب المجمـوعتين الضـابطة والتجريبيـة التـي درســـ المعهـل الافتراضــي

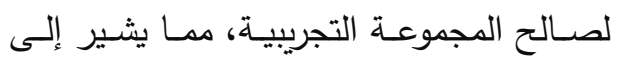
التأثير الإيجابي للمعدل الافتراضـي في تتمية المهـارات العمليـة لـدى الطـلاب شـعبة فنـي لإي معامـل بالمــارس الثانويـة الزراعيـة، ومـن ثم

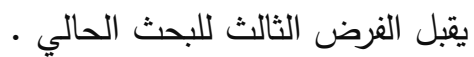
اختبار صحة الفرض الر ابع للبحث:

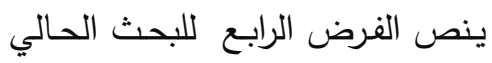

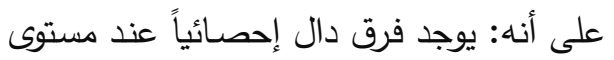

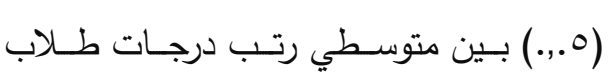
وتجريب عملي تعيش من خلالها الطالبات

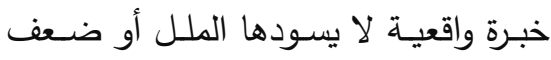

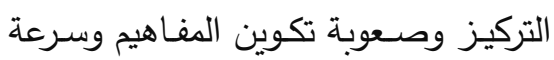
نسيانها .

ثانياً : مناقتشة النتائج المتعلقة ببطاقة ملاحظـة المهار ات العملية : اختبار صحة الفرض الثالث :

ينص الفرض الثالث للبحث الحالي على لهى أنه: يوجد فرق دال إحصائياً عند مستوى (0.ر. ) بين متوسطي رتب درجات طلاب المجموعة

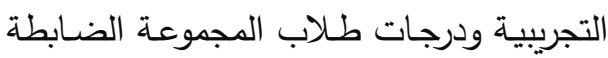
في التطبيق البعدي لبطاقة ملاحظة المهارات العملية لصالح المجموعة التجريبية. وللتحقق من صحة هذا الفرض، تم

استخدام (اختبار مان ويتني Mann Whitney ) للفرق بين المجموعات المستقلة لتحديد دلالة

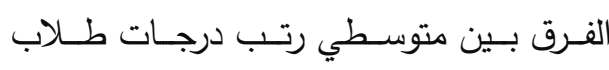

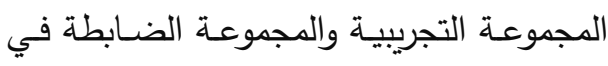

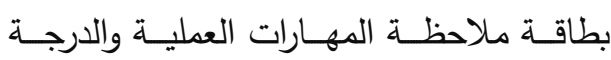
الكلية، تمهيداً لتحديد فعالية المعمل الافتراضي لهي

\section{rqq}




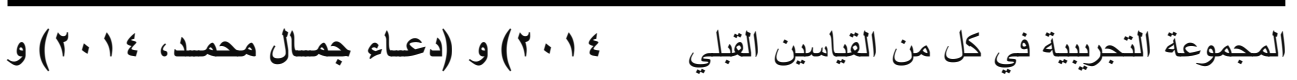

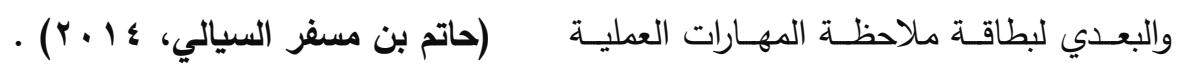

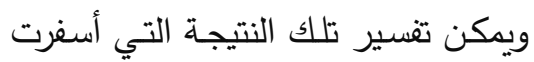

$$
\begin{aligned}
& \text { لصالح التطبيق البعدي. }
\end{aligned}
$$

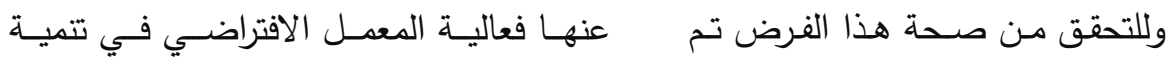

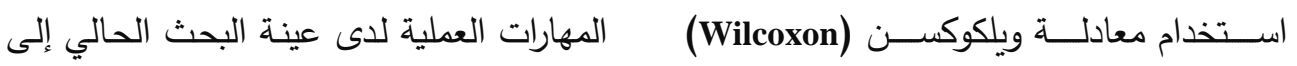

$$
\begin{aligned}
& \text { لإشـارات الرتب كأسلوب إحصائي لابارامتري، ما يلي: }
\end{aligned}
$$

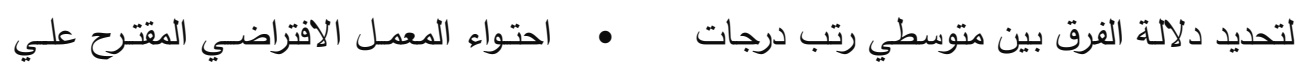

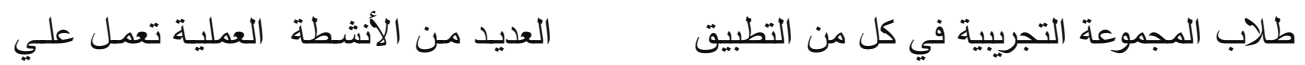

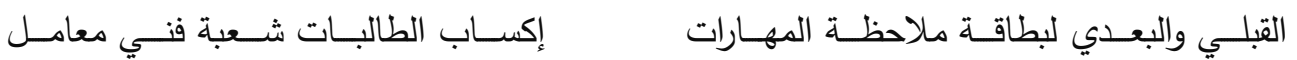

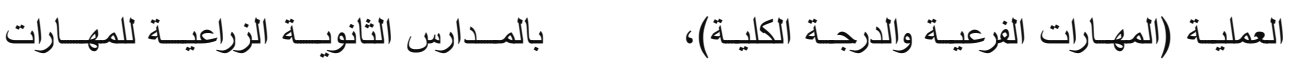

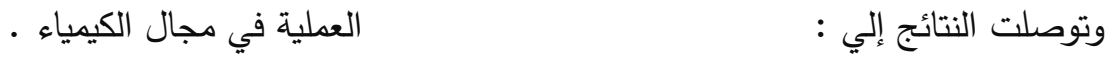

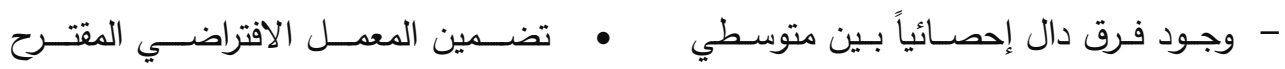

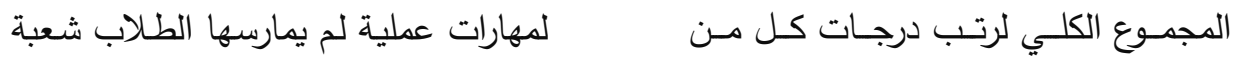

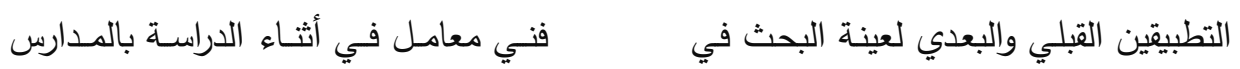

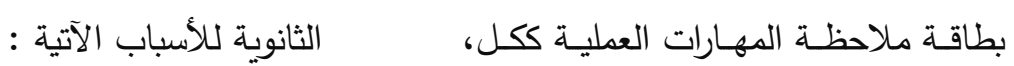

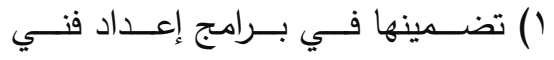

$$
\begin{aligned}
& \text { المعامل، ولكن بصـورة مُوجزة لا تفي الكي } \\
& \text { لاكتساب تلك المهارات، مما يدل علي }
\end{aligned}
$$

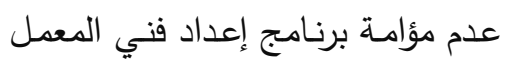

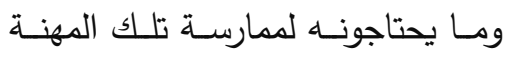

$$
\begin{aligned}
& \text { مثل: مهارة تحضير غـاز الأكسجين، } \\
& \text { مهارة الكثف عن شق البوتاسيوم في }
\end{aligned}
$$

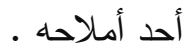

$$
\begin{aligned}
& \text { r) خطـورة أداء بعض المضه لمهارات العمليـة } \\
& \text { مثـل التجــارب التـي تحتــاج تسـخين } \\
& \text { لدرجة حرارة عالية مثل: مهارة فصل لئل } \\
& \text { مخلوط من الرصاص والرمل. }
\end{aligned}
$$

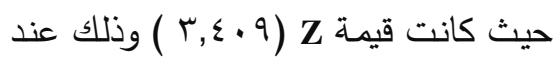

$$
\begin{aligned}
& \text { مستوى (0.. • ) لصالح التطبيق البعدي. }
\end{aligned}
$$

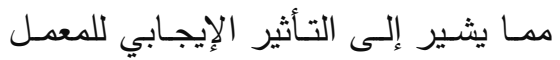

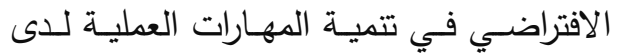

$$
\begin{aligned}
& \text { الطـلاب شعبة فنـي معامل بالمدارس الثانويـة } \\
& \text { الزراعيـة، ومـن ثم يقبل الفرض الرابع للبحث } \\
& \text { الحالي } \\
& \text { وتتفق هذه النتيجة مـع نتائج دراسـة كل }
\end{aligned}
$$

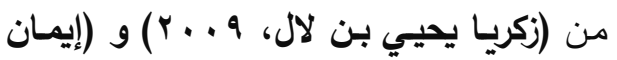

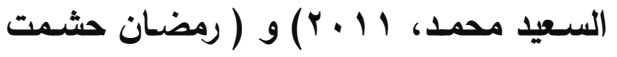

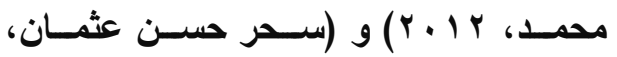


طــلاب كـل مــن المجموعـــة التجريبيـة والمجموعـة الضـابطة في مقيـاس الاتجـاه نحـو العهـل المعملـي الافتراضـي، وكـان

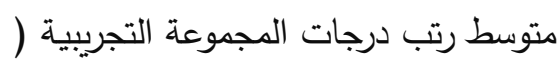

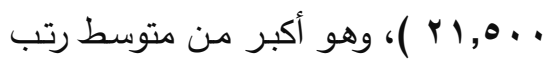
المجموعة الضابطة ( . . 9,0 ) .

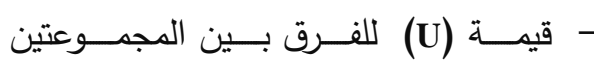
التجريبيـة والضـابطة في مقيـاس الاتجـاه

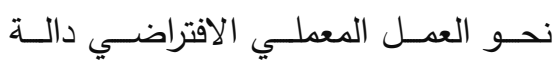
لصـالح المجموعـة التجريبيـة حيث كـان متوسطي رتب درجات المجموعة التجريبية أكبر من متوسطي رتب درجات المجموعة

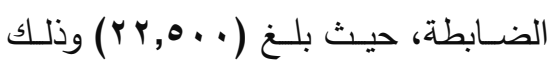
في القياس البعدي، مما يشير إلى وجود

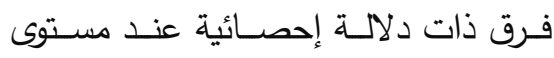

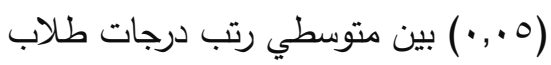

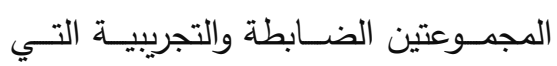

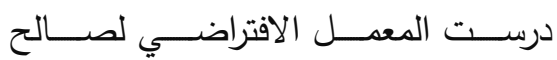
المجموعة التجريبية، ومن ثم يقبل الفرض لمرض

$$
\text { الخامس للبحث الحالي }
$$
اختبار صحة الفرض البحث السادي للبحث:

ينص الفرض السادس للبحث الحالي

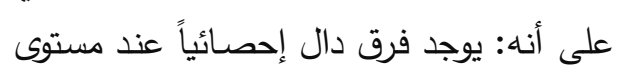

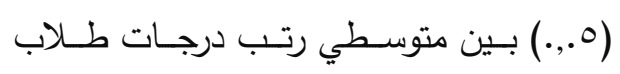
المجموعة التجريبية في كل من القياسين القبلي

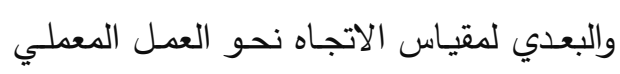
الافتراضي لصالح التطبيق البعدي . r) ارتفــاع تكـاليف أداء بعضض المهـارة؛

حيث تحتاج أداء بعض المهارات إلي

مواد وأدوات لاتتوافر في المدارس مثل

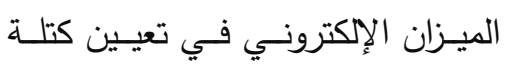

جسـم صـلب أو سـائل مُقـدراً بـالمللي · جرام

ثالثـاً : مناقثــة النتائج المتعلقة بمقيـاس الاتجـاه نحو العمل المعطلي الافتر اضي : ختبار صحة الفرض الخامس للبحث:

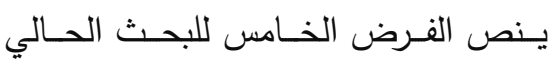

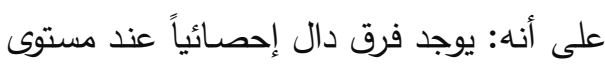

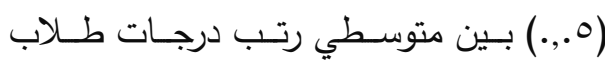

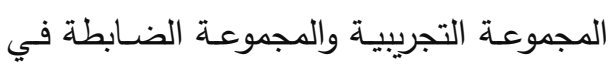

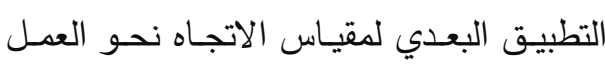

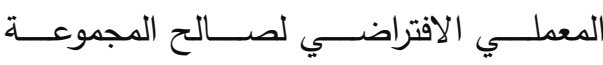
التجريبية. وللتحقق من صحة هذا الفرض، تم

استخدام اختبار (مان ويتني Mann Whitney) للفرق بين المجموعات المستقلة لتحديد دلالة

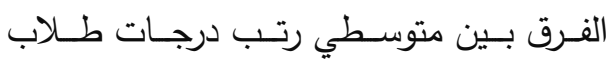

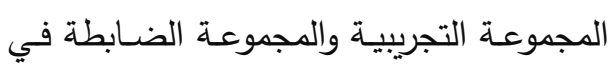
مقياس الاتجاه نحو العمل المعملي الافتراضي

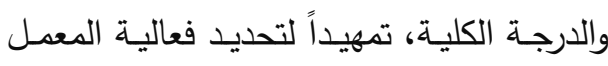

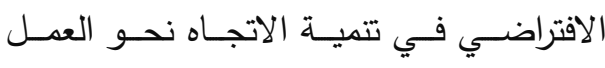
المعملي الافتراضي، وتوصلت النتائج إلي

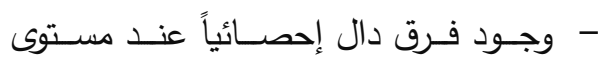

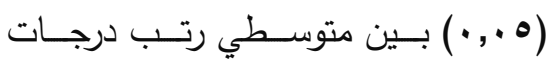




$$
\begin{aligned}
& \text { وللتحقق من صحة هذا الفرض تم استخدام الثانويـة الزراعيـة عــــ مقارنـة القيـاس القبلـي } \\
& \text { معادلة (ويلكوكسن (Wilcoxon) لإشارات الرتب بالبعدي لطالبات المجموعة التجريبية إلي : }
\end{aligned}
$$

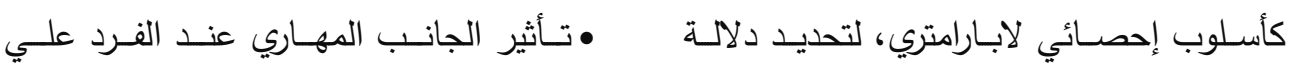

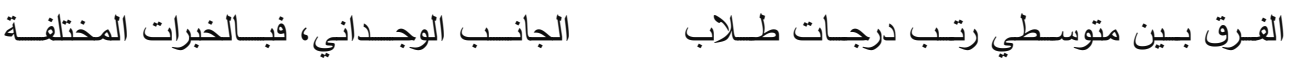

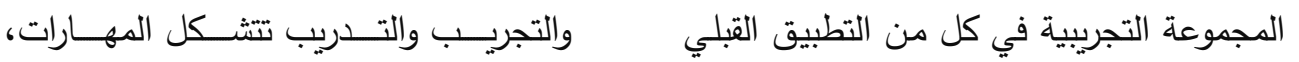

$$
\begin{aligned}
& \text { والبعدي لمقياس الاتجاه نحو العمل المعملي والمهارات بدورها تئثر في السلوك والاتجاه }
\end{aligned}
$$

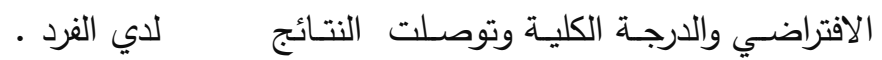

$$
\begin{aligned}
& \text { • طريقة التدريس المستخدمة في تتفيذ المعمل لون }
\end{aligned}
$$

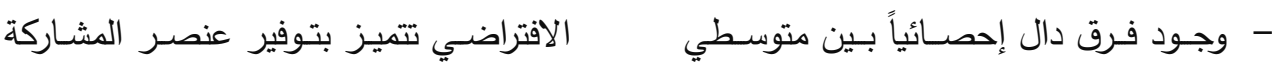

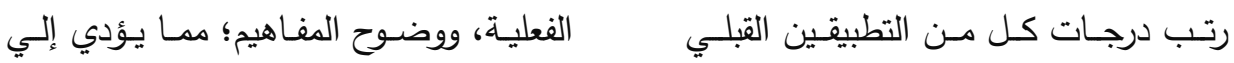

$$
\begin{aligned}
& \text { والبعدي لعينة البحث في مقياس الاتجاه التشـويق والانتبـاه، ويجعل الطالبـات أكثر }
\end{aligned}
$$

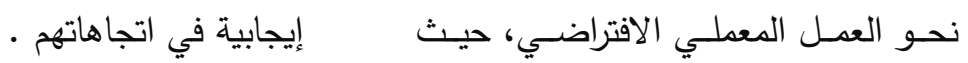

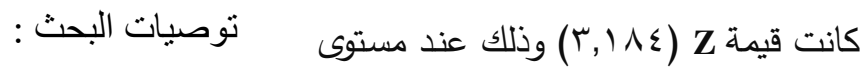

$$
\begin{aligned}
& \text { في ضوء ما تم التوصل إليه من نتائج يوصي }
\end{aligned}
$$

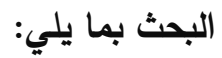

$$
\begin{aligned}
& \text { ( ) إجراء مزيــ من البحـوث والدراسـات التي لي } \\
& \text { تتتـاول أثر استخدام المعامل الافتراضية } \\
& \text { فـي تــديس مقـررات آخـري كالفيزيــاء } \\
& \text { والأحياء علي تنمية المهارات العملية علي دربي } \\
& \text { طلاب شعبة فني معامل بالمدارس الثانوية } \\
& \text { الزراعية . }
\end{aligned}
$$

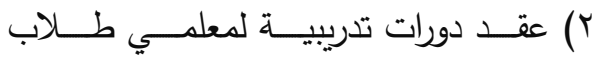

$$
\begin{aligned}
& \text { المــارس الثانويـة الزراعيـة شـعبة فنـي }
\end{aligned}
$$

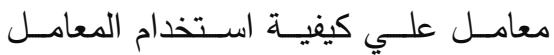

$$
\begin{aligned}
& \text { الافتراضية في تدريس مادة العلوم بفروعها } \\
& \text { (0., , ) لصالح التطبيق البعدي. }
\end{aligned}
$$

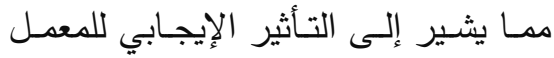

$$
\begin{aligned}
& \text { الافتراضي في تتمية مقياس الاتجاه نحو العمل الإلي }
\end{aligned}
$$

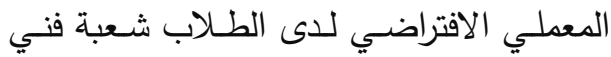

$$
\begin{aligned}
& \text { معامـل بالمــارس الثانويـة الزراعيـة، ومـن ثـم } \\
& \text { يقبل الفرض السادس للبحث الحالي }
\end{aligned}
$$

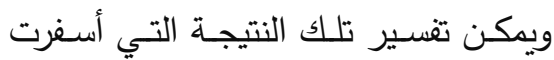

$$
\begin{aligned}
& \text { عنهـا فعاليـة المعدـل الافقراضــي في تتميـة }
\end{aligned}
$$

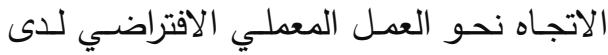

$$
\begin{aligned}
& \text { عينة البحث الحالي إلى ما يلي: }
\end{aligned}
$$

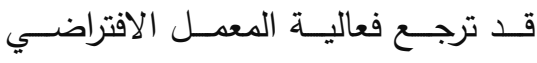

$$
\begin{aligned}
& \text { المقترح في تتمية الاتجاه نحو العمل المعملي } \\
& \text { الافتراضي لدي طالبات الصف الثاني الثانوي } \\
& \text { الزراعي شعبة فني معامل بمدرسة كفر صقر لاعري }
\end{aligned}
$$




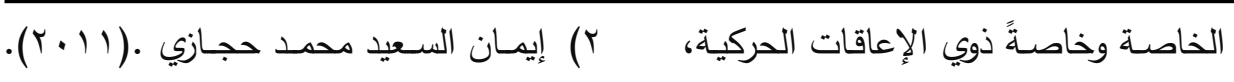

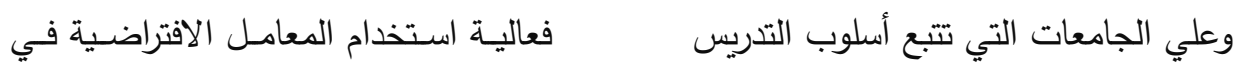

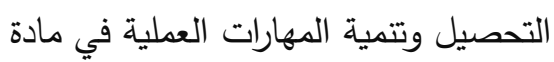

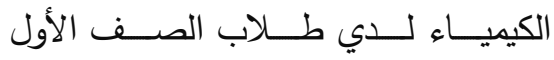

$$
\begin{aligned}
& \text { الثـانوي. رسـالة ماجسـتير غيـر منشـورة }
\end{aligned}
$$

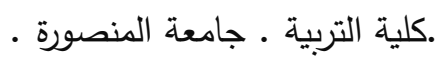

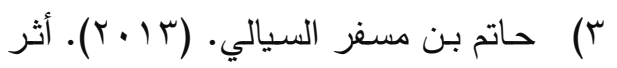

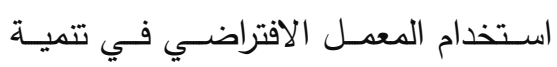

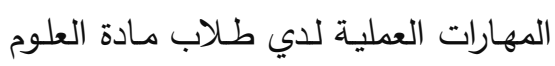

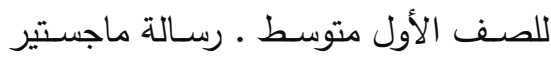

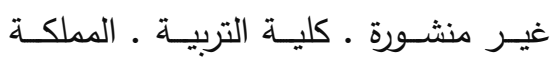

$$
\begin{aligned}
& \text { العربية السعودية ـ جامعة أم القري. }
\end{aligned}
$$

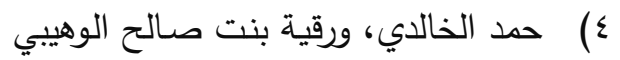

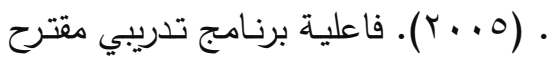

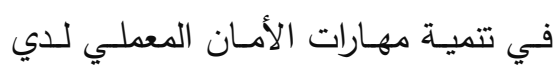

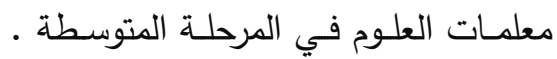

$$
\begin{aligned}
& \text { دراسـات فـي المنــاهج وطـرق التـدريس } \\
& \text { مجلـة المنـاهج وطرق التدريس ـ العدد. }
\end{aligned}
$$

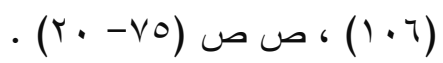

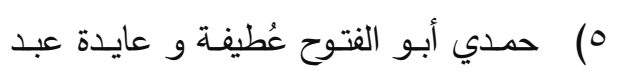

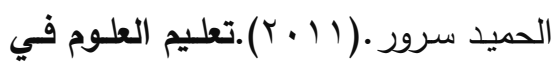

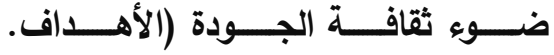

$$
\begin{aligned}
& \text { والإســتراتيجيات ).القـاهرة : دار النثـر }
\end{aligned}
$$

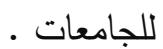

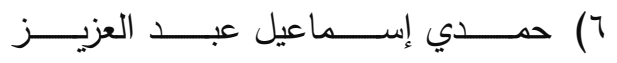

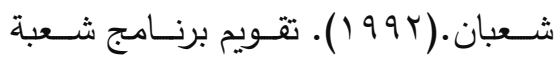

$$
\begin{aligned}
& \text { أمنـاء المعامل بالمدارس الثانويـة الزراعية }
\end{aligned}
$$

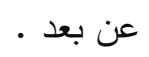

$$
\begin{aligned}
& \text { ع) التعـــاون بــين المؤسســــات التعليميــــة } \\
& \text { ومؤسسات إنتاج برامج الواقع الافتراضـي لـاتي }
\end{aligned}
$$

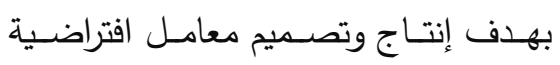

$$
\begin{aligned}
& \text { عاليـة الجـودة ومناسبة للمنـاهج الدراسية }
\end{aligned}
$$

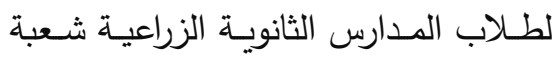

$$
\begin{aligned}
& \text { فني معامل . } \\
& \text { مقترحات البحث : } \\
& \text { تقترح الباحثة در اسة ما يلي : }
\end{aligned}
$$

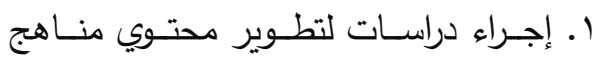

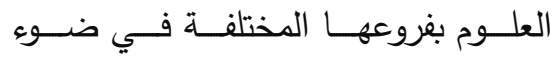

$$
\begin{aligned}
& \text { المهارات العملية لطلاب المدارس الثانويـة } \\
& \text { الزراعية شعبة فني معامل. } \\
& \text { r. إجـراء دراسـة للتعـرف علـي أثر برنـامج } \\
& \text { تـدريبي لمعلدي الكيميـاء علـي تتميــة }
\end{aligned}
$$

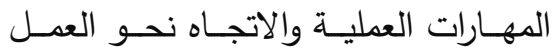

$$
\begin{aligned}
& \text { المعملي الافتراضي لدي طلاب شعبة فني } \\
& \text { معامل بالمدارس الثانوية الزراعية . } \\
& \text { r. إجراء دراسة لاستخدام المعامل الافتراضية } \\
& \text { في المدارس التي تُعني بذوي الاحتياجات } \\
& \text { الخاصة وخاصة ذو الإعاقات الحركية . } \\
& \text { المر اجع العربية : العاصة } \\
& \text { ( ) إبراهيم بسيوني وفتحي الديب ـ ( IVVV). } \\
& \text { تدريس العلوم والتربية العلمية. القاهرة : } \\
& \text { دار المعارف للنشر والتوزيع • لدابل }
\end{aligned}
$$




\begin{tabular}{|c|c|}
\hline 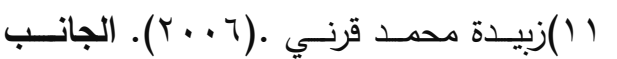 & فـي ضـــوء اكتســاب الطــلاب المهــارات \\
\hline الوجـاني في تــريس العلـوم .المنصـورة & العمليــة اللازمــة لعملهــم كأمنــاء معامـلـ \\
\hline :المكتبة العربية . & الكيمياء بالمدارس الثانويـة العامـة ـ رسـالة \\
\hline 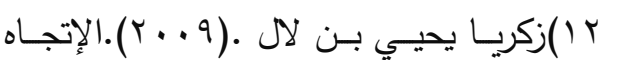 & ماجستير.غيـر منشـورة. معهد الدراسـات \\
\hline نحـو استخدام المختبـرات الافتراضـية في & والبحوث التزبوية. جامعة القاهرة . \\
\hline التعلـيم الإلكترونـــي وعلاقتـــه بــبعض & خالـ حمدي ومحمد سـالم وأحمد علي . \\
\hline القدرات الإبداعيـة لـدي عينـة مـن طـلاب & 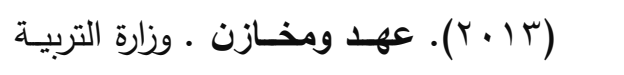 \\
\hline وطالبـات التعليم الثانوي في مدينـة مكـة & والتعليم : المصرية للطباعة . \\
\hline المكرمة بالمملكة العربية السعودية .مجلة & 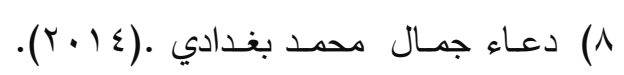 \\
\hline اتحــاد الجامعــات العربيـة ـالأردن ربيـع & فاعلية تصميم معدل افتراضسي قائم علي \\
\hline 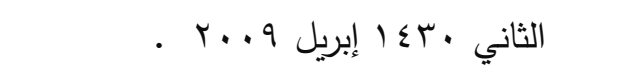 & التفاعلات المتعددة لتتمية بعض مهارات \\
\hline 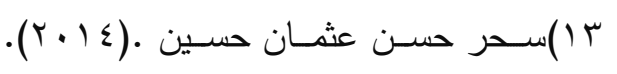 & التجــارب المعمليــة فـي مـــهج الكيميـاء \\
\hline تــأثير اسـتخدام المعــل الافتراضــي في & لطـلاب الصـف الأول الثـانوي • رسـالة \\
\hline تتمية المهارات العملية وعمليات العلم لدي & ماجسـتير غيـر منشــورة ـ كليـة التربيـة \\
\hline طلاب الصف السادس الابتدائي • رسالة & النوعيـة قســ تكنولوجيـا التعليم · جامعـة \\
\hline ماجسـتير غيـر منشـورة ـ كليـة التربيـة. & بورسعيد . \\
\hline جامعة عين شمس • & 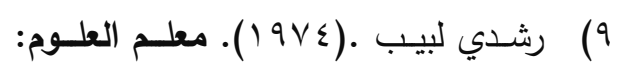 \\
\hline ع () صـبري باسـط أحمــ.(ب999 (). معوقـات & مسئولياته،أسـاليب عملـه، إعداده ونمـوه \\
\hline 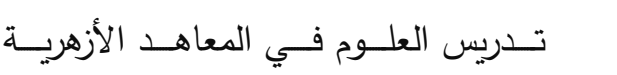 & العلمي والمهني .القاهرة : مكتبة الأنجلو \\
\hline بمحافظــة سـوهاج .المجلــة التربويـــة : & المصرية . ل \\
\hline مطبعة الجامعة بسوهاج.عدد^.جزء . & 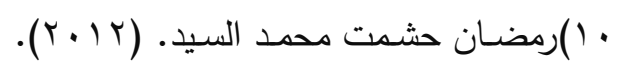 \\
\hline 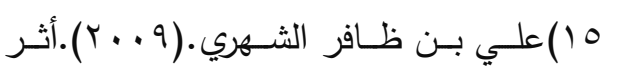 & أثر التفاعل بـين أنمـاط العمل بالمعاملـ \\
\hline اســتخدام المختبــرات الافتراضـــية فــي & الافقراضـية لمقـررات العــوم والأســاليب \\
\hline اكتســاب مهـارات التجـارب المعمليـة في & المعرفية في تتمية الأداء المعملي لطلاب \\
\hline مقـرر الأحيـاء لطــلاب الصــف الثالـث & المرحلــة الاعداديـة ـ رسـالة دكتوراة غيـر \\
\hline الثانوي بمدينـة جدة. رسـالة دكتوراة غير & منشورة كلية التربية جامعة حلوان · \\
\hline
\end{tabular}


http://ecenter.mans.edu.eg/doc/virtual-

From : lap.pdf

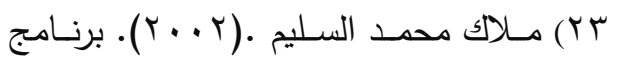

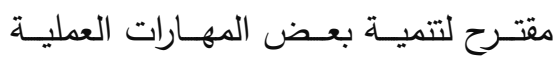

الكيميائيـة المدرسـية لـدي طالبـات كليـة

التربية للبنـات بالريـاض • رسـالة الخليج

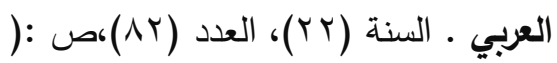

$$
\begin{aligned}
& \text { - (IVT،11) } \\
& \text { المر اجع الأجنبية : }
\end{aligned}
$$

1. Australian Science Teachers Association . (2010). The Proceedings of the National Forum on the Role and Support Structures for Laboratory Technicians in Australian Secondary Schools . Retrieved on :1/9/2015 from :http://www.asta.edu.au/

freestyler/files/Lab Tech Forum Proceedings .doc

2. Australian Science Teachers Association .(2013). School Science Laboratory Technicians National Stanards 2013.Retrieved on : 15/7/2015 From: http://www.asta.edu.au/freestler/files /Lab tec forum proceedi . Doc.

3. Christina ,H \& Pamela, $M$ \& Amanda ,B \& John,L \& Richard, G.(2000). What is the purpose of this Experiment ? Or Can Students Learn From Experiments ? Journal of Research in Science Teaching . Vol .(37), NO.(7), PP. (655-675).

4. CLEAPSS. (2009). G228 Technicians and their jops. Retrieved on 13/6/2015 from: http:www. Cleapss .org.uk

5. Darrah, $M$ \& Humbert .R \& Finstein ,J \& Simon , $M$ \& Hopkins and John.(2014). Are Virtual Labs as Effective as Hands - on Labs For undergraduate physic? A comparative study at Two Major University. Journal of Science Education and
منشــورة .كليـة التربيـة .المملكـة العربيـة

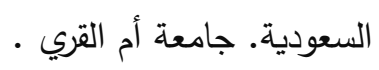

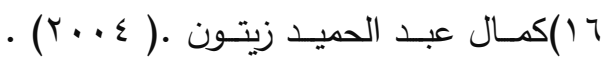

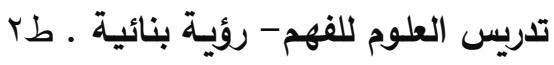

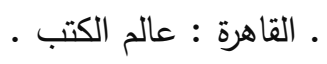

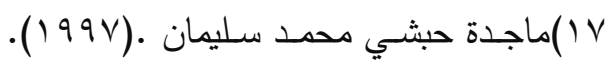

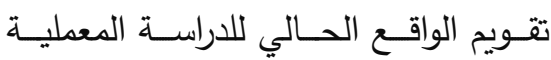

بمراحل التعليم العـام ـ المـؤتمر العلمـي لـولي

الأول للجمعية المصرية للتربية العلمية .

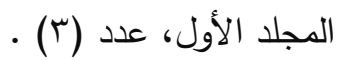

A ( )ماهر إسماعيل صبري.(99 99 ( ). الأمسان

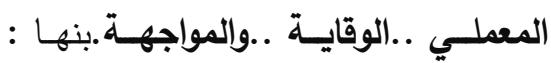

مؤسسة الإخلاص للطباعة والنشر .

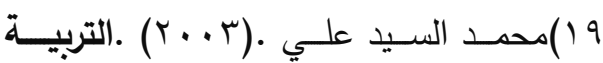

العلمية وتدريس العلوم.عمّان:دار المسيرة

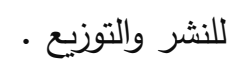

• Y)محمد صـابر سـليم و سـعد عبد الوهـاب "

نادر • (9VY I ). الجديد في تدريس العلوم

ـ طץ. القاهرة : مطبعة المعرفة .

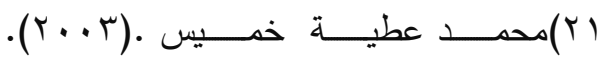

منتوجات تكنولوجيا التعليم .القاهرة : دار

$$
\text { الحكمة . }
$$

rYr)المركز القومي للتعليم الإككتروني بالمجلس

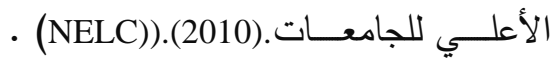

دليل إرشادي ونموذج التقدم لطلب إتاحة

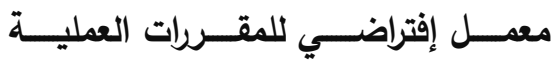

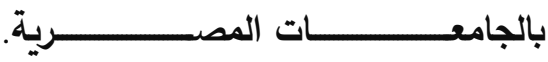


http://www.lancshre.gov.uk/education/ swg/training and development jops/science_technician/index.sp.

12. Subramanian \& Rajarm \& Marsic \& Ivan.(2001).VIBE:Virtual Biology Experiments ,TheState University of New Jersey. Retrieved on 20/8/2015 from: www10.org/cdrom/ papers/ 513/index.html Tatli, Z \& Ayas ,A . (2012). Virtual chemistry laboratory : Effect of constructivist learn in Environment. Turkish Online Journal of Distance Education .Vol(13), No(1),PP183- 199. Jan .

13. The Royal Society and Assosiation for Science Education .(2001).Survey of science technicians in Schools and colleges London:The Royal Society. Retrieved on 7/3/2015, from : http:// royalsociety.org/uploaded Files/Royal Society_Content/ Influencing _policy/Education/Reports/Survey of science Tec hnicians in School and colleges.pdf.

14. U.S.B of Labor statistic .(2013).What is a lab technician?.Retrieved on 15/8/2015, From: Learn.org/ articles/ what_do_Laboratory

_Assistant_do.html.

15. Weisman,D.(2012). In corporating a collaborative web-based Virtual laboratory in an undergraduate bioinformatic course-. Journal of Biochemistry \& Molecular Biology Education . Vol (38), No(1), PP 4-9
Technology. No.(6),P.803-814.

$\operatorname{Vol}(23)$,

6. Dillion, J .(2008). A Review of the Research on Practical Work in School Science Kings College London .

7. Feyzigolou, B \& Baris, D \& Alev, A \& Ilker ,C \& Eralp , A . (2011). ChemstryTeachers Perceptions on Laboratory Applications : Izmir Sample. Education Sciences: Theory \& Practice. Vol (11), No.(2), PP: $1024-1029$.

8. Nivalainen, V \& Asikainen, A \& Hirvonen, E . (2013). Preservice Teachers Objectives and Their Experience of Practical Work .Physical Review Special TopicsPhysics - Education Research .Vol.(9) No.(1), PP .1-17.

9. Poulin, J \& Rammamurthy,B \& Dithmar, K. (2013). Toward a better understanding of population genetics : pop! World: A Virtual inquiry based tools for teaching population genetics. Journal of College Science Teaching. Vol (42), No(3), PP3237,Jan .

10. Pyatt, K \& Smis , R.(2012). Virtual and Physical experimentation in inquiry based science lab : Attitudes, performance and access. Journal of Science Education and Technology ,Vol (21) ,No(1) ,PP 133-147 Feb .

11. Stang,P,J.(2014).Science Technician. Journal of the Americian Chemical Society Retrieved on 3/8/2015 from: 